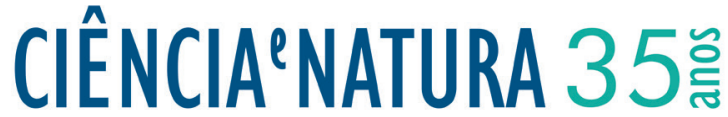

\section{Genética e suas aplicações: identificando o conhecimento presente entre concluintes do ensino médio}

\author{
Genetics and its applications: identifying this knowledge among high school senior \\ students
}

\author{
Daiana Sonego Temp ${ }^{1}$, Marlise Ladvocat Bartholomei-Santos ${ }^{2}$ \\ ${ }^{1}$ Doutoranda, Universidade Federal de Santa Maria, Santa Maria, Brasil \\ ${ }^{2}$ Doutora., Universidade Federal de Santa Maria, Santa Maria, Brasil
}

\begin{abstract}
Resumo
O presente artigo apresenta os resultados obtidos em uma pesquisa com estudantes concluintes do ensino médio, matriculados em duas escolas, uma pública e outra privada, localizadas na cidade de Santa Maria, RS, Brasil. O objetivo principal foi identificar os conhecimentos de genética e suas relações, apresentados pelos alunos após um ano do conteúdo ser estudado nas escolas. A pesquisa utilizou abordagens qualitativa e quantitativa, sendo realizadas através da utilização de um questionário composto por questões que abordavam conteúdos de genética e suas correlações presentes nos principais exames de vestibular. Os resultados mostraram que os alunos apresentam concepções errôneas relacionadas a diferentes conteúdos de genética, como herança do DNA mitocondrial, produção de clones e transgênicos, projeto genoma humano e relação entre genótipo, fenótipo e meio ambiente. A aquisição de conceitos corretos ligados à genética é fundamental para que estes estudantes compreendam as diversas tecnologias relacionadas à manipulação do DNA, tenham condições para opinar e realizar escolhas em situações relacionadas ao tema, como no caso de alimentos transgênicos e aconselhamento genético. Assim, é necessário que o processo de ensino seja revisto para que os alunos tenham acesso a conhecimentos corretos, ou seja, ocorra a alfabetização científica nas escolas.
\end{abstract}

Palavras-chave: Genética. Alunos. Ensino médio. Conhecimento. Biotecnologia.

\begin{abstract}
This article presents the results from a survey of high school senior students enrolled in two schools, one public and one private, located in the town of Santa Maria, Rio Grande do Sul state, Brazil. The study aimed to identify the student's knowledge on genetics and its relationships after one year of studying the contents at school. Qualitative and quantitative approaches were used by means of a questionnaire with questions on genetics contents and their correlations, modified from college admission exams. Results showed that students present misconceptions related to several issues on genetics, such as the mitochondrial DNA inheritance, the production of clones and transgenic organisms, the human genome project, relationships among genotype, phenotype and environment. The acquisition of correct conceptions related to genetics is essential for the understanding, by the students, of the several technologies involving DNA manipulation, and thereby allowing the conditions to opine and make choices in situations related to the subject, as in the case of transgenic food and genetic counseling. Thus, it is necessary to review the teaching processes so that students can have access to correct knowledge, and scientific literacy occurs at school.
\end{abstract}

Keywords: Genetics. Students. High school. Knowledge. Biotechnology. 


\section{Introdução}

Uma das funções da escola é auxiliar os alunos a compreenderem e se posicionarem frente às diferentes situações que irão enfrentar na sociedade (Lane e Codo, 1993). Temas relevantes relacionados à política, saúde e educação necessitam de espaço para discussão. Desta forma o aluno estará recebendo a orientação necessária para que possa escolher suas decisões.

A disciplina de Biologia perpassa diferentes áreas do conhecimento. Em especial, temos na Genética uma área central (Kreuzer e Massey, 2002) que se relaciona com questões éticas, políticas, de saúde, familiares, econômicas, entre outras. Assim, ensinar genética vai além da resolução de exercícios de herança, pois é um momento onde temas atuais relacionados à aplicação das biotecnologias poderão ser expostos e explicados de forma correta (Gericke et al., 2012).

O ensino e a aprendizagem de genética são considerados, por diferentes autores, como os mais difíceis dentro da Biologia (Kovaleski e Araújo, 2013; Gercke, 2012; Klautau et al., 2009; Barbosa, 2008; Castelão e Amabis, 2008; Moreira e Silva, 2001; Amorim, 1997). A interrelação de conteúdos e matérias, a existência de conceitos abstratos e o excesso de terminologias e metodologias inadequadas são fatores que propiciam a dificuldade da consolidação da aprendizagem (Williams et al., 2012; Boneti, 2006).

Diferentes estudos mostram que os estudantes não apresentam os conhecimentos básicos de genética, como a relação genes-cromossomos- DNA e a capacidade de relacionar os processos de divisão celular com hereditariedade (Santos, 2005; Scheid e Ferrari, 2006; Temp e Bartholomei- Santos, 2013). Mas, para compreender as aplicações da genética na sociedade, é necessário que os alunos tenham o conhecimento básico de genética (Justina, 2001).

Compreender genética é indispensável para que ocorra a aprendizagem científica (Giacoia, 2006), mas há necessidade de rever e atualizar as metodologias que proporcionem a construção do conhecimento (Krasilchik, 2004). O processo de ensino que leve a real aprendizagem é aquele que explora relações entre ideias, conceitos e semelhanças, solucionando erros conceituais (Moreira, 2011).

Educar em genética requer a priorização da formação de um estudante que compreenda a localização, transmissão e variação nas características hereditárias (Ayuso e Banet, 2002).

Redfield (2012) sugere um currículo que contemple um curso de genética de acordo com as necessidades do século XXI, considerado o século do gene (Meyer et al., 2011). Entre os conteúdos apontados estão: genômica pessoal, variação natural nas populações, estrutura e função dos genes e cromossomos, variações surgidas por mutação, como os genes afetam os fenótipos, mitose e meiose (mecanismos e consequências genéticas).
O século XX foi marcado pelo grande avanço da genética nas diferentes áreas do conhecimento. Temas como células-tronco, clonagem, seleção de embriões, aconselhamento genético e alimentos transgênicos fazem parte de discussões nos mais variados ambientes e meios de comunicação (Santos, 2005).

Assim, a escola e os professores necessitam estar conscientes sobre a importância da alfabetização científica relacionada aos conhecimentos em genética, suas relações, por exemplo, com a biotecnologia, e aplicações (Kim e Irving, 2010; Primon, 2005). Um dos objetivos da educação escolar é o ensino de uma ciência atual compatível com a realidade (Carvalho, 1992).

Entre as implicações da genética relacionadas à biotecnologia podemos citar a possibilidade de descobrir a origem e tratamento de doenças hereditárias, criar plantas com maior produtividade, produzir hormônios com auxílio de bactérias e a criação de vacinas que salvam milhões de vidas anualmente (Williams et al., 2012).

Como os conhecimentos relacionados à genética estão em constante expansão, tornam-se necessárias discussões frequentes para eleger quais conteúdos são essenciais para o ensino (Franzolin e Bizzo, 2012; Ayuso e Banet, 2002) e para a formação de pessoas com sólido conhecimento científico, que podem compreender melhor as decisões tomadas em uma sociedade (Hoffman, 1992).

Devido à importância de um aprendizado significativo em genética para a formação de cidadãos conscientes, $\mathrm{o}$ objetivo deste trabalho foi identificar quais conhecimentos de genética e suas aplicações alunos concluintes do ensino médio, de duas escolas, apresentaram após um ano de o conteúdo ter sido estudado.

\section{Metodologia}

Participaram da pesquisa 154 alunos (87 do sexo feminino e 67 do sexo masculino), matriculados no terceiro ano do Ensino Médio (EM), no segundo semestre de 2013, em duas escolas localizadas na cidade de Santa Maria, RS.

Os alunos desta série foram escolhidos porque estudaram genética no ano anterior (2012), permitindo observar se eles consolidaram a aprendizagem dos conteúdos deste tema ministrado dentro da disciplina de Biologia (Ausubel et al., 1980).

Para o desenvolvimento desta pesquisa foram utilizadas as abordagens qualitativa e quantitativa. A pesquisa qualitativa possui o ambiente natural como fonte direta de dados e o pesquisador como instrumento principal (Lüdke e André, 1986). As abordagens quali e quantitativas diferem quanto à forma e à ênfase, porém os métodos qualitativos trazem como contribuição ao trabalho do pesquisador uma mistura de procedimentos de cunho racional e intuitivo capazes de contribuir para a melhor compreensão dos fenômenos (Neves, 1996). 


\subsection{Identificando as escolas}

A escola designada por A é uma instituição privada que atende alunos da educação infantil até o final do ensino médio. O terceiro ano do EM era representado por uma turma composta por 45 alunos. Destes, 39 responderam a pesquisa. A disciplina de Biologia é ministrada em 4 horas aulas semanais (180 min.) no segundo ano do EM (série que se estuda genética).

A escola B é uma instituição pública estadual, possuindo apenas turmas do EM. O terceiro ano era composto por sete turmas (301 a 307), perfazendo um total de 196 alunos matriculados. Destes, 115 participaram da pesquisa. Nesta escola, a disciplina de Biologia, para as turmas de segundo ano do EM, é dividida entre duas professoras (7 turmas para cada). Os alunos têm 2 períodos semanais de Biologia (90 min.).

\subsection{Coleta e análise dos dados}

Para a coleta dos dados utilizou-se um questionário composto por 12 questões, adaptadas de diferentes provas de vestibulares, que buscavam identificar os conhecimentos dos alunos em relação aos conteúdos de genética estudados no EM, principalmente aqueles relacionados à biotecnologia (Anexo 1). Os temas das questões estão apresentados no Quadro 1. As questões eram compostas por uma frase afirmativa. Após a leitura, o aluno escolhia uma alternativa entre: verdadeira; falsa; estudei, mas esqueci; não vi isto no colégio, podendo justificar sua escolha.

Para a análise dos dados, as questões foram agrupadas em duas categorias, de acordo com a temática das

frases. As categorias criadas são: nível celular (questões 1, 2, 3, 9 e 12) e aplicações da genética (questões 4, $5,6,7,8,10$ e 11).

As respostas foram divididas em 5 tipos: certa com justificativa correta; certa com justificativa errada; errada; estudei, mas esqueci; e nunca estudei no colégio.

\section{Resultados}

Os resultados relacionados à categoria nível celular, composta pelas questões 1, 2, 3, 9, 12, são apresentados na Tabela 1.

Na questão 1 - relacionada à presença de DNA em todas as células sanguíneas - encontramos semelhança nos percentuais de respostas. Nas escolas A e B, 56\% e $57 \%$ dos participantes responderam de forma incorreta a questão. Ao justificarem sua escolha, independentemente da escola, os alunos escreveram que todas as células apresentam DNA localizado no interior do núcleo, não

Quadro 1: Temas presentes nas 12 questões formadoras do teste utilizado com os alunos do terceiro ano do Ensino Médio nas duas escolas.

\begin{tabular}{|c|l|}
\hline Questão & Tema \\
\hline 1 & $\begin{array}{l}\text { Presença de DNA em todos os tipos de células sanguíneas } \\
\text { humanas }\end{array}$ \\
\hline 2 & Identificação de cadáveres através do DNA mitocondrial \\
\hline 3 & $\begin{array}{l}\text { Definição de paternidade quando os pais são gêmeos mono ou } \\
\text { dizigóticos }\end{array}$ \\
\hline 4 & Origem das características genéticas de um clone \\
\hline 5 & Exemplo de transgênico \\
\hline 6 & Melhoramento genético executado por agricultores \\
\hline 7 & $\begin{array}{l}\text { Produção da insulina humana em bactérias como exemplo de } \\
\text { engenharia genética }\end{array}$ \\
\hline 8 & Inserção de genes de interesse em um organismo transgênico \\
\hline 9 & Definição da paternidade através da análise das bandas de DNA \\
\hline 10 & Sequenciamento do genoma humano \\
\hline 11 & Biotecnologia e bioética relacionadas à plantação de transgênicos \\
\hline 12 & $\begin{array}{l}\text { Interação do genótipo com o meio ambiente determinando o } \\
\text { fenótipo }\end{array}$ \\
\hline
\end{tabular}


Tabela 1. Frequências absolutas e relativas dos tipos de respostas dos alunos com relação aos conhecimentos em genética na categoria nível celular.

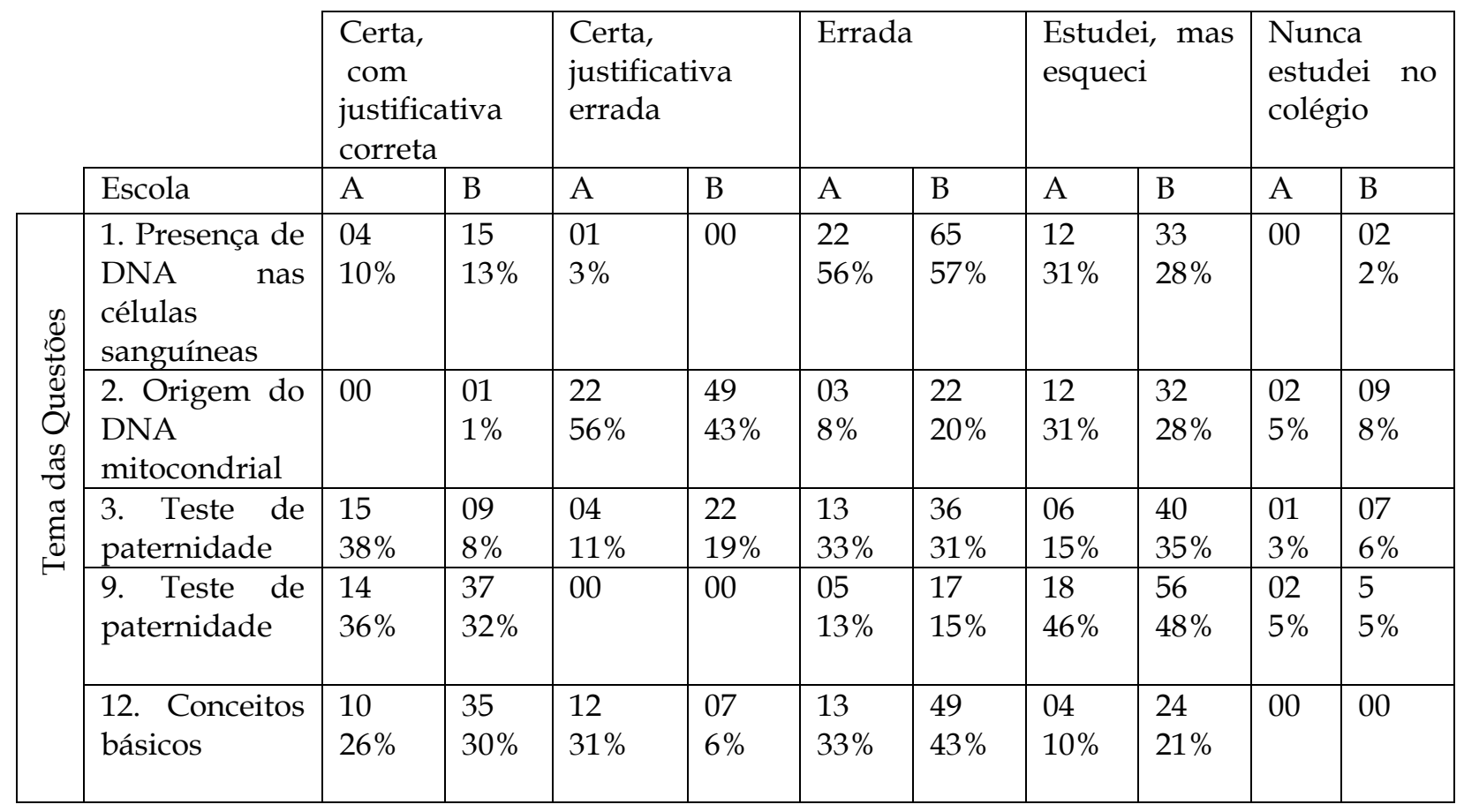

reconhecendo que alguns tipos celulares perdem o núcleo no processo de maturação.

"Para ser uma célula tem que ter DNA" (A);

“Todas as células apresentam membrana, citpoplasma e núcleo." (B).

Entre os alunos que acertaram a questão, e justificaram de forma correta sua escolha, também encontramos semelhanças entre as respostas. A principal justificativa está relacionada à ausência de DNA nas hemácias. Na escola A um aluno relacionou a ausência de núcleo neste tipo celular como uma adaptação ao transporte de oxigênio $\left(\mathrm{O}_{2}\right)$ e três alunos escreveram que as plaquetas são fragmentos celulares.

“Plaquetas não possuem DNA." (A);

"As hemácias transportam oxigênio, para aumentar o espaço não apresentam núcleo". (A);

"Hemácias nascem com núcleo e depois perdem." (B).

O conhecimento sobre a herança materna do DNA mitocondrial é tema da questão 2 . Como resultado, $56 \%$ dos alunos da escola A e $43 \%$ dos alunos da escola B marcaram a alternativa correta, mas justificaram a resposta de forma errônea. Nas duas escolas os participantes consideram que o DNA mitocondrial é originário da união (durante a fecundação) do DNA materno e
DNA paterno.

“DNA mitocondrial não é sempre herdado da mãe” (A);

“O DNA é do pai e da mãe juntos" (A);

“É herdado do pai e da mãe" (B).

“O DNA mitocondrial é a junção das características paternas e maternas" (B)

As questões 3 e 9 discutiam aplicações da genética (teste de paternidade), com o conhecimento sobre a origem de gêmeos monozigóticos e dizigóticos e a análise de bandas de DNA para a confirmação da paternidade.

$\mathrm{Na}$ questão 3 os alunos deveriam identificar, no caso de um exame de paternidade, em qual dos casos o resultado seria confiável: quando os pais eram gêmeos mono ou dizigóticos.

Neste caso, os resultados apresentaram certa diferença entre as escolas. Na escola A, 38\% dos alunos responderam e justificaram de forma correta a questão e 33\% responderam incorretamente.

$\mathrm{Na}$ escola B, 31\% acertaram a resposta e 35\% responderam que estudaram o conteúdo, mas esqueceram.

Os participantes, das duas escolas, que acertaram e justificaram corretamente sua resposta escreveram que gêmeos monozigóticos, por serem originários de um mesmo óvulo e mesmo espermatozoide, apresentam material genético igual. 
“Gêmeos monozigóticos têm o mesmo padrão de fragmentos de DNA, então não teria como saber quem é o pai" (A);

“São monozigóticos, possuem o mesmo DNA, não é possível identificar" (B);

“Como Renato é filho de um homem que é gêmeo monozigótico (vem do mesmo zigoto) é impossível saber quem é o pai, pois os irmãos têm o mesmo DNA" (B).

A questão 9 apresentava uma imagem que comparava o padrão de DNA de uma criança com o padrão de 4 casais que reclamavam a paternidade do menino. Nas duas escolas os resultados foram semelhantes: $46 \%$ da escola A e $48 \%$ da escola B assinalaram a alternativa "estudei o conteúdo, mas esqueci".

Os alunos que acertaram e justificaram corretamente a questão (36\% da escola A e 32\% da escola B) apresentaram justificativas semelhantes. Eles analisaram a imagem e compararam os padrões de bandas do menino e dos casais.

“É mais provável que os pais do bebê 81 sejam o casal C, devido a maior quantidade de bandas semelhantes" (A);

“Os pais do bebê são o casal C. O D não pode ser por causa do $8^{\circ}, 10^{\circ}, 11^{\circ}, 12^{\circ}$ e $14^{\circ}$ traços de cima para baixo, que do bebê são diferentes" (A);

"As fitas não correspondem. O certo seria o C" (B);
“Não se completam os genes do pai e da mãe" (B).

O estudo do conteúdo de genética é permeado pelo aprendizado de diferentes conceitos. A relação entre genótipo, fenótipo e meio ambiente foi o tema da questão 12.

Como resultado, 33\% dos alunos da escola A e 43\% da escola B erraram a questão. Os alunos demonstraram certa confusão no momento de definir os conceitos ou responderam que características genéticas não sofrem interações com o meio ambiente.

"A característica cor da pele é determinada pelo genótipo humano" (A);

“O meio não interfere em característica como esta. A cor da pele tem valor apenas com a genética do indivíduo" (A);

"A característica cor da pele é definida pelo genótipo" (B).

A segunda categoria - aplicações da genética -, composta pelas questões $4,5,6,7,8,10$ e 11 , tem seus resultados apresentados na Tabela 2.

A questão 4 trazia como tema principal o conceito de clonagem. No texto, o aluno precisava compreender que o clone apresenta características genéticas iguais ao do ser doador de DNA.

$\mathrm{Na}$ escola A, encontramos $43 \%$ de respostas corretas e $44 \%$ de respostas erradas e, na escola B, temos apenas $27 \%$ de respostas justificadas corretamente e $45 \%$ de respostas erradas.

Tabela 2: Frequências absolutas e relativas dos tipos de respostas dos alunos com relação aos conhecimentos em genética na categoria aplicações da genética.

\begin{tabular}{|c|c|c|c|c|c|c|c|c|c|c|c|}
\hline & \multirow[b]{2}{*}{ Escola } & \multicolumn{2}{|c|}{$\begin{array}{l}\text { Certa, com } \\
\text { justificativa } \\
\text { correta }\end{array}$} & \multicolumn{2}{|c|}{$\begin{array}{l}\text { Certa, } \\
\text { justificativa } \\
\text { errada }\end{array}$} & \multicolumn{2}{|c|}{ Errada } & \multicolumn{2}{|c|}{$\begin{array}{l}\text { Estudei, mas } \\
\text { esqueci }\end{array}$} & \multicolumn{2}{|c|}{$\begin{array}{l}\text { Nunca } \\
\text { estudei no } \\
\text { colégio }\end{array}$} \\
\hline & & A & $\mathrm{B}$ & A & B & A & B & A & B & A & B \\
\hline \multirow{7}{*}{ 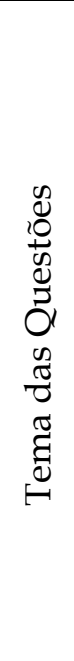 } & 4.Clonagem & $\begin{array}{l}17 \\
43 \%\end{array}$ & $\begin{array}{l}31 \\
27 \%\end{array}$ & $\begin{array}{l}03 \\
8 \%\end{array}$ & $\begin{array}{l}03 \\
3 \%\end{array}$ & $\begin{array}{l}17 \\
44 \%\end{array}$ & $\begin{array}{l}52 \\
45 \%\end{array}$ & $\begin{array}{l}02 \\
5 \%\end{array}$ & $\begin{array}{l}22 \\
19 \%\end{array}$ & 00 & $\begin{array}{l}07 \\
6 \%\end{array}$ \\
\hline & 5.Transgênico & $\begin{array}{l}33 \\
84 \%\end{array}$ & $\begin{array}{l}74 \\
65 \%\end{array}$ & 00 & 00 & 00 & $\begin{array}{l}07 \\
6 \%\end{array}$ & $\begin{array}{l}05 \\
13 \%\end{array}$ & $\begin{array}{l}29 \\
25 \%\end{array}$ & $\begin{array}{l}01 \\
3 \%\end{array}$ & $\begin{array}{l}04 \\
4 \%\end{array}$ \\
\hline & $\begin{array}{l}\text { 6.Melhoramen } \\
\text { to genético }\end{array}$ & $\begin{array}{l}31 \\
79 \% \\
\end{array}$ & $\begin{array}{l}67 \\
59 \%\end{array}$ & 00 & $\begin{array}{l}01 \\
1 \% \\
\end{array}$ & $\begin{array}{l}03 \\
8 \%\end{array}$ & $\begin{array}{l}19 \\
17 \%\end{array}$ & $\begin{array}{l}03 \\
8 \%\end{array}$ & $\begin{array}{l}18 \\
16 \% \\
\end{array}$ & $\begin{array}{l}02 \\
5 \%\end{array}$ & $\begin{array}{l}09 \\
7 \%\end{array}$ \\
\hline & $\begin{array}{l}\text { 7. Engenharia } \\
\text { genética }\end{array}$ & $\begin{array}{l}18 \\
45 \%\end{array}$ & $\begin{array}{l}35 \\
30 \%\end{array}$ & 00 & 00 & $\begin{array}{l}01 \\
3 \%\end{array}$ & $\begin{array}{l}16 \\
14 \%\end{array}$ & $\begin{array}{l}12 \\
31 \%\end{array}$ & $\begin{array}{l}38 \\
33 \%\end{array}$ & $\begin{array}{l}08 \\
21 \%\end{array}$ & $\begin{array}{l}26 \\
23 \%\end{array}$ \\
\hline & $\begin{array}{l}\text { 8.Produção de } \\
\text { transgênico: }\end{array}$ & $\begin{array}{l}19 \\
49 \% \\
\end{array}$ & $\begin{array}{l}39 \\
34 \% \\
\end{array}$ & $\begin{array}{l}06 \\
15 \% \\
\end{array}$ & $\begin{array}{l}07 \\
6 \% \\
\end{array}$ & $\begin{array}{l}01 \\
3 \% \\
\end{array}$ & $\begin{array}{ll}23 \\
20 \% \\
\end{array}$ & $\begin{array}{l}11 \\
28 \% \\
\end{array}$ & $\begin{array}{l}24 \\
21 \% \\
\end{array}$ & $\begin{array}{l}2 \\
5 \% \\
\end{array}$ & $\begin{array}{l}22 \\
19 \% \\
\end{array}$ \\
\hline & $\begin{array}{l}\text { 10. Genoma } \\
\text { humano }\end{array}$ & $\begin{array}{l}04 \\
10 \% \\
\end{array}$ & $\begin{array}{l}23 \\
20 \%\end{array}$ & $\begin{array}{l}08 \\
21 \%\end{array}$ & $\begin{array}{l}08 \\
7 \%\end{array}$ & $\begin{array}{l}10 \\
26 \%\end{array}$ & $\begin{array}{l}36 \\
31 \%\end{array}$ & $\begin{array}{l}13 \\
33 \%\end{array}$ & $\begin{array}{l}33 \\
29 \% \\
\end{array}$ & $\begin{array}{l}04 \\
10 \%\end{array}$ & $\begin{array}{l}15 \\
13 \% \\
\end{array}$ \\
\hline & 11.Bioética & $\begin{array}{l}12 \\
31 \%\end{array}$ & $\begin{array}{l}22 \\
19 \%\end{array}$ & 00 & 00 & $\begin{array}{l}17 \\
44 \%\end{array}$ & $\begin{array}{l}43 \\
38 \%\end{array}$ & $\begin{array}{l}08 \\
20 \%\end{array}$ & $\begin{array}{l}38 \\
33 \%\end{array}$ & $\begin{array}{l}02 \\
5 \%\end{array}$ & $\begin{array}{l}12 \\
10 \%\end{array}$ \\
\hline
\end{tabular}


Entre os alunos que acertaram as respostas, verificamos que os mesmos apresentam o conhecimento de que as características genéticas são herdadas daquele ser que doou o núcleo para o experimento.

“O animal terá as características genéticas do jumento, pois ele foi o doador do núcleo" (A);

“Terá as características do jumento, pois o DNA usado foi o dele" (B).

Considerando as justificativas escritas pelos alunos que erraram a questão, encontramos semelhanças entre as respostas: o clone será uma mistura do DNA dos diferentes seres que participaram do experimento.

“Não só da égua, terá uma mistura de todos os outros" (A);

“Terá as características dos dois: égua e jumento” (B).

As questões 5 e 8 exploram o conhecimento sobre transgênicos. Na questão 5 os alunos identificavam o conceito através de um exemplo. Já na questão 8 era apresentado um caso onde, após a leitura de uma notícia, o aluno precisava compreender que o gene desejado deveria ser inserido no zigoto ou no embrião e não em todas as células adultas do ser receptor.

Com relação à questão 5, 84\% dos alunos da escola A e $65 \%$ da escola B responderam de forma correta. Nenhum aluno justificou esta questão.

A questão 8 apresentou, na escola A, 46\% e, na escola B, $48 \%$ de respostas corretas. As justificativas apontam que estes alunos compreendem que, ao inserir o gene desejável no zigoto, através das divisões celulares (mitose), este gene será transmitido às outras células do organismo.

“O DNA da medusa foi introduzido apenas na primeira célula (ovo ou zigoto), assim ela se multiplica por mitose e passa as características para as outras";

"O trecho de DNA pode ser inserido apenas no zigoto, depois ele se espalha" (B).

Entre os alunos que erraram, 3\% da escola A e 20\% da escola B, a justificativa principal é que este tipo de técnica não existe.

“Não é possível juntar gene de medusa com um coelho" (A);

“Este experimento não existe" (B).

O conhecimento sobre melhoramento genético praticado por agricultores desde a antiguidade é o tema da questão 6.

Na escola A, $45 \%$ dos alunos acertaram a questão e na escola B, 30\%. Nenhum destes alunos justificou sua resposta.

Entre os alunos que erraram, 8\% da escola A e 17\% da escola B, a justificativa principal é de que não existe melhoramento genético sem a utilização de conhecimento de laboratório e tecnologia.

A questão 7 trata de um exemplo de engenharia genética: produção de insulina humana por bactérias. Acertaram a questão $45 \%$ dos alunos da escola A e 30\% da escola B. Os alunos não justificaram sua escolha.

O Projeto Genoma Humano é a temática da questão 10. Os dados apontam que apenas $10 \%$ dos alunos da escola A e $20 \%$ da escola B apresentavam conhecimento sobre o tema. Entre estes alunos, a justificativa está relacionada ao descobrimento da sequência das bases formadoras do genoma humano e não da codificação de todas as proteínas.

“Não são conhecidas todas as proteínas, mas a sequência de bases" (A);

“São muitas proteínas, nem todas são conhecidas" (B).

Entre os alunos que erraram a questão, encontramos certa confusão de termos como genótipo, genoma, código genético.

“Genoma são os genes, não as proteínas” (A);

“Decifraram o genótipo e não o genoma" (B).

O tema destaque da questão 11 é bioética. O número de erros foi $44 \%$ na escola A e $38 \%$ na escola B. Nenhum destes alunos justificou sua resposta.

Entre os alunos que acertaram a questão, 31\% da escola A e $19 \%$ da escola B, percebemos que eles compreendem a possibilidade de transmissão do gene transgênico através da reprodução.

“Há esse risco a não ser que a planta resistente ao herbicida seja modificada para não produzir gametas" (A);

“O DNA com o gene transgênico pode ser transmitido, por exemplo, pelo grão-de-pólen" (B).

\section{Discussão}

O estudo e entendimento das funções e características celulares são considerados como conhecimentos básicos na Biologia.

Compreender os diferentes tipos celulares, suas funções e relações nos organismos, torna-se fundamental para a aprendizagem dos mais diversos temas, entre eles a genética.

A categoria Nível celular (Tabela 1) é composta por questões que relacionam conceitos básicos de biologia celular e genética, aliados às aplicações da genética. 
Nesta categoria não observamos variação significativa nas respostas dos alunos das duas escolas: escola A, particular, e escola B, estadual.

As semelhanças entre os resultados podem estar relacionadas à classificação destes conceitos como essenciais para o ensino e aprendizagem dos conteúdos de genética e suas correlações.

A aprendizagem do DNA como a "molécula da vida" tem seu início nos primeiros anos do ensino fundamental - anos finais - e continua permeando a biologia durante toda a vida do estudante.

Porém, diferentes trabalhos mostram que a maioria dos estudantes, mesmo após a conclusão do EM, apresentam concepções equivocadas com relação ao DNA, como sua presença apenas nas células dos animais, a conviç̧ão de que não comeriam alimentos que contivessem DNA e a dificuldade em relacionar a tríade gene-cromossomo-DNA (Ayuso e Banet, 2002; Loreto e Sepel, 2003; Scheid e Ferrari, 2006; Pedrancini et al., 2007; Williams et al., 2012; Temp e Bartholomei-Santos, 2013).

Esses resultados mostram que a escolarização não é suficiente para levar à formação de um aprendizado cientificamente correto. A sólida compreensão de conceitos como DNA, cromossomos e genes é fundamental para o entendimento de questões polêmicas presentes no dia-a-dia (Pedrancini et al., 2007).

As questões 1 e 2 da presente pesquisa estavam relacionadas ao DNA: presença da molécula em todas as células e herança do DNA mitocondrial, respectivamente.

A maioria dos estudantes respondeu de forma incorreta as questões e utilizaram justificativa que contrariam o ensino realizado nas escolas.

Com relação à presença de DNA em todas as células, encontramos nas justificativas que "uma célula tem que ter DNA no interior do núcleo". Embora isto seja verdadeiro para a maioria das células eucarióticas, este tipo de resposta mostra uma compreensão incompleta de fenômenos celulares, como o fato de hemácias maduras de mamíferos serem células anucleadas e organismos procariontes não apresentarem núcleo.

O estudo das células sanguíneas, entre elas as hemácias, inicia no $1^{\underline{o}}$ ano do EM, onde as mesmas servem como exemplo de células anucleadas. No $2^{\circ}$ Ano do EM, o tema é intensificado junto com o estudo do Sistema Circulatório, onde as funções e características das células sanguíneas são relacionadas. Também no estudo do Reino Animal, principalmente Classe Mammalia (mamíferos), é feita uma caracterização das hemácias dos mamíferos, justamente por não apresentarem núcleo.

Outro ponto em destaque é a colocação de que "todas as células apresentam núcleo". O estudo da citologia inicia, normalmente, no 5o ano do Ensino Fundamental (EF), onde o aluno é apresentado à estrutura celular como formadora dos seres vivos.

Nos anos seguintes, o conhecimento vai sendo aprofundado, sendo que, no $7^{\circ}$ ano, conceitos mais específicos, como procariontes e eucariontes, são apresentados e exemplificados.

Os estudantes, ao responderem que todos os seres vivos possuem células nucleadas, mostram esquecimento com relação a um expressivo grupo de seres vivos: os representantes do Reino Monera, composto por bactérias e cianobactérias.

É importante salientar que 31\% dos alunos da escola A e $28 \%$ da escola B responderam que "estudaram o conteúdo, mas esqueceram", ou seja, ocorreu apenas memorização dos conteúdos em detrimento de uma aprendizagem significativa.

Este fato pode estar relacionado à fragmentação dos conteúdos e à memorização de conceitos (Mortimer, 1996).

A $2^{\underline{a}}$ questão referia-se à herança do DNA mitocondrial. Como resultado temos que nenhum aluno da escola A e apenas 1 aluno da escola B acertou a questão.

O DNA mitocondrial é herdado a partir das mitocôndrias presentes no óvulo (gameta feminino), ou seja, não há participação paterna neste padrão de herança (com raras exceções).

A principal justificativa apresentada pelos alunos é que o DNA mitocondrial é uma "mistura do DNA paterno e do DNA materno". Assim, observamos que ocorre confusão entre herança do DNA nuclear com herança do DNA mitocondrial.

Mas, por que é importante para o aluno compreender este padrão de herança? Principalmente porque diferentes distúrbios genéticos, como alguns tipos de deficiências auditivas e doenças neuromusculares, são herdados a partir deste padrão. Também porque o DNA mitocondrial pode ser utilizado para a identificação de corpos, solução de casos de maternidade duvidosa, definição de linhagens genéticas, entre outras (Zatz, 2012).

O reconhecimento dos diferentes padrões de herança pode ser considerado como tema de alfabetização científica, pois qualifica o indivíduo a compreender o que está sendo noticiado, ler um artigo e perceber a relação do DNA mitocondrial com o contexto, entender a importância da "Eva mitocondrial" para os estudos da ancestralidade humana, entre diversas situações. O ensino de genética e suas correlações facilita o entendimentos das questões sociais e tecnológicas relacionadas ao assunto (Ayuso e Banet, 2002). Geneticistas enfatizam que as pessoas, por não entenderem conceitos básicos, como alelos, genes, padrões de herança, meiose e cromossomos, muitas vezes não compreendem as informações fornecidas durante o aconselhamento genético (Santos, 2005).

Podemos questionar se este conteúdo foi trabalhado com os alunos. Mas, ao analisarmos a Tabela 1, encontramos que $31 \%$ dos alunos da escola A e $28 \%$ da B responderam: "estudei o conteúdo, mas esqueci".

Novamente nos deparamos com um modelo de ensino falho para a formação e consolidação do conhecimento. O ensino promovido no ambiente escolar não tem conseguido promover a apropriação dos conhecimentos científicos de modo a utilizá-los em situações que exigem reflexão (Mortimer, 1996). 
É interessante colocar que esta questão fez parte da prova do Exame Nacional do Ensino Médio (ENEM) no ano de 2013, ou seja, após a coleta de dados com os alunos participantes desta pesquisa.

Entre as aplicações da genética, o teste de paternidade pode ser considerado como uma das mais conhecidas envolvendo a análise do DNA. Este teste é realizado a partir da comparação de sequências de DNA dos indivíduos em questão, por exemplo, suposto pai e filho.

As questões 3 e 8 buscaram identificar o conhecimento dos estudantes, com relação ao teste de DNA como uma aplicação da genética, para a solução de casos de paternidade duvidosa ou desconhecida. As questões sobre as diferenças e semelhanças entre gêmeos idênticos pode ser o ponto de partida para analisar a reprodução sexual como fonte de variabilidade (Ayuso e Banet, 2002).

Na questão 3 foram citados conceitos como gêmeos monozigóticos e dizigóticos, comparação de sequências de DNA e fecundação.

Neste caso, observamos certa diferença entre as escolas A e B. Na escola A (particular), 38\% dos estudantes responderam de forma correta a questão, enquanto, na escola B, apenas $8 \%$ dos estudantes acertaram a mesma.

As justificativas apresentadas foram baseadas em diferentes conceitos que mostraram o conhecimento com relação à diferença entre gêmeos monozigóticos e dizigóticos. Os aspectos mais descritos estão relacionados ao tipo de formação do zigoto e composição genética dos mesmos.

Esta diferença nos acertos entre as escolas pode estar relacionada a dois fatores: em primeiro lugar, o número de aulas: na escola A, de cunho particular, os alunos têm 4 horas/aula de biologia (180 min.) por semana, enquanto na escola B, estadual, este número é de 2 horas/aula (90 min.), ou seja, a carga horária é reduzida à metade.

Devido a esta maior carga horária, os professores da escola A utilizam nas suas aulas, além do ensino da genética clássica, materiais que abordam conteúdos relacionados à aplicação da genética, como no caso dos testes de paternidade. Aprender genética demanda tempo para que o aluno compreenda os conceitos e consiga relacioná-los (Ayuso e Banet, 2002).

O segundo fator que pode estar envolvido é a maior preocupação em preparar os estudantes para os vestibulares: a escola A é reconhecida por seu ensino, principalmente no EM, estar voltado ao preparo dos alunos para diferentes exames de vestibular.

O maior número de aulas, a existência de simulados, a realização, de forma orientada, de exercícios retirados dos principais exames do país são fatores que disponibilizam ao aluno maior contato com questões contextualizadas e interrelacionadas. Professores de escola particular são cobrados com relação à aprovação dos alunos nos vestibulares (Franzolin, 2012).

A abordagem do teste de paternidade também pode ser um momento para o professor abordar temas transversais (Brasil, 2000), como gravidez na adolescência e responsabilidade.

A questão 9 apresentava uma imagem representativa da impressão "digital" de DNA de alguns casais e de uma criança, para identificar o casal genitor da criança. Para responder corretamente o estudante precisava saber que metade da informação genética da criança é herdada do genitor materno e a outra metade do genitor paterno e comparar os padrões "digitais" do DNA entre pais e filho.

Nesta questão, $46 \%$ dos alunos da escola A e $48 \%$ da escola B responderam "estudei, mas esqueci". Essas respostas refletem a ausência de um conhecimento mais duradouro, pois o aluno tem a lembrança do conteúdo, mas, passado certo tempo, não consegue aplicá-lo. Uma questão semelhante estava presente na prova do ENEM no ano de 2013.

Diversos estudos mostram que os alunos confundem conceitos interrelacionados ou não conseguem fazer a relação correta entre eles. Há dificuldade em relacionar meiose e reprodução e meiose com a produção de filhos diferentes dos pais (Redfield, 2012; Pedrancini et al., 2007).

Conceitos como gene, genótipo, genoma e código genético são considerados por estudantes, em diferentes níveis de ensino, como sinônimos (Silveira, 2014). Para outros, DNA e cromossomos são estruturas diferentes localizadas no núcleo celular. Na pesquisa de Franzolin (2012, p. 126), um dos professores entrevistados respondeu que:

“a expressão código genético vem sendo abordada como algo particular de cada indivíduo, ou seja, como se cada organismo tivesse seu próprio código genético, em vez de considerar o código genético como universal".

Professores acreditam que a falta de embasamento teórico, aliado a pouca importância dada ao conteúdo, é o fator mais relevante para a formação destas concepções erradas (Justina e Barradas, 2003).

Mas, para que o estudante consiga compreender as mudanças e novidades relacionadas à genética, ele precisa dominar os conceitos básicos desta área, tais como a natureza do material genético, padrões de herança, expressão gênica e sua regulação, variação genética e evolução (Franzolin, 2012). Caso contrário, a sua compreensão será equivocada ou incompleta, não gerando um conhecimento significativo.

A questão número 12 explorava a relação entre os conceitos de genótipo, fenótipo e meio ambiente. Ao ler o enunciado da questão, o aluno identificava se os conceitos estavam aplicados de forma correta.

Como resultado, 33\% de respostas incorretas na escola A e $43 \%$ na B.

Os alunos confundiram os conceitos de genótipo e fenótipo ou não relacionaram o meio ambiente como um fator importante para a expressão das características genéticas.

Estes conceitos são ensinados desde o início do ensino 
de genética. Então, podemos concluir que o modelo atual de ensino não leva à consolidação de um aprendizado correto.

A função da escola de formar cidadãos críticos, conscientes, informados e atuantes na sociedade não está acontecendo de forma completamente satisfatória.

A segunda categoria - Aplicações da Genética (Tabela 2) - é composta por questões onde o conhecimento relacionado à aplicação da genética é abordado em diferentes contextos. A abordagem deste tema na escola auxilia os alunos a estudarem este conteúdo de forma estruturada, pois a informação veiculada pela mídia pode ser enganosa e tendenciosa (Franzolin, 2012).

A compreensão destes temas é considerada como importante para a formação científica dos estudantes, pois inúmeros produtos originados a partir da biotecnologia, como soja e arroz transgênicos, roupas oriundas de algodão modificado, insulina humana produzida por bactérias, são utilizados pela população (Ayuso e Banet, 2002).

$\mathrm{Na}$ questão 4 o tema abordado foi clonagem. O estudante deveria identificar que o clone apresenta características genéticas iguais ao organismo doador do DNA. Este tema ganhou destaque com o nascimento da ovelha Dolly, em 1996 (Kreuzer e Massey, 2002). A notícia da clonagem do primeiro mamífero, veiculada em 1997, levou a diferentes questionamentos: será possível clonar seres humanos? Os clones têm expectativa de vida menor?

Os alunos que erraram a questão mostraram não compreender o processo básico de clonagem: o material genético (DNA nuclear) de um doador é inserido em uma célula gamética anucleada, desenvolvendo um embrião (Amabis e Martho, 2009).

A justificativa incorreta mais frequente estava relacionada à formação do clone como uma mistura de material genético dos diferentes seres participantes do processo.

Esta concepção mostra que os alunos não relacionaram material genético (DNA) com características genéticas. $\mathrm{Na}$ realidade, eles entenderam que a herança genética está relacionada com a célula como um todo.

Para que estas concepções errôneas sejam modificadas é necessário que o conhecimento seja apresentado de uma forma que se torne atrativo e, principalmente, tenha uma relação com a realidade (Ayuso e Banet, 2002).

$\mathrm{O}$ uso de textos científicos, pesquisas orientadas e modelos didáticos são ferramentas que auxiliam para o desenvolvimento da aprendizagem significativa (Miranda, 2001).

Pesquisas mostram que é na escola onde as mudanças conceituais acontecem, pois há espaço para a abordagem, de forma correta, de temas relacionados à biotecnologia e suas correlações (Santos, 2008).

Outro tema de destaque são os transgênicos: organismos vivos modificados em laboratório, onde se introduz uma ou mais sequências de genes de interesses provenientes de outra espécie (Kreuzer e Massey, 2002).
A discussão em torno dos transgênicos teve seu auge relacionado à produção de sementes transgênicas, como soja e arroz. A mídia divulgava pesquisas apontando se a população era a favor ou contra o plantio destas sementes (Justina e Barradas, 2003). As pessoas discutiam os possíveis danos destes grãos à saúde. Ambientalistas perguntavam sobre o risco para o meio ambiente (Pedrancini et al., 2008). Porém, quando estas pessoas eram questionadas sobre a origem destes grãos, normalmente não apresentavam o conhecimento correto.

As questões 5 e 8 tratavam sobre este tema de duas formas. Na questão 5 o texto descrevia o conceito de organismo transgênico e na questão 8 era apresentado um caso de transgenia, com a transferência de um gene de água viva para um coelho.

Nas duas questões a maioria dos alunos, independente da escola, respondeu corretamente.

Com relação à questão 8 , observamos, entre os alunos que erraram a questão, a dificuldade em compreender que, para a formação do "coelho transgênico", o gene de interesse, proveniente da água viva, seria inserido no zigoto.

As justificativas apresentadas se relacionam com a impossibilidade deste experimento ser realizado. Para estes alunos, transgênicos são apenas algumas plantas criadas em laboratório.

Esta visão pode estar relacionada com o modelo de ensino onde se utilizam como exemplos de transgênicos apenas os alimentos de origem vegetal. Assim, o aluno retém um conhecimento incompleto, que pode induzi-lo a interpretações equivocadas quando, por exemplo, ler um texto, ouvir uma notícia ou encontrar a identificação de produtos transgênicos nos rótulos de alimentos.

No estudo realizado por Justina \& Barradas (2003), $53 \%$ dos professores de biologia acreditam que transgênicos fazem mal à saúde, $27 \%$ acham que deve haver mais pesquisas e $20 \%$ responderam que os transgênicos são inofensivos. Estas concepções também podem influenciar na aprendizagem dos alunos.

Temas como clonagem e transgênicos precisam ser trabalhados de forma diferencial para que não ocorra a formação de indivíduos com concepções errôneas. Os estudantes enfrentarão situações na vida onde precisarão avaliar substâncias oferecidas pelo mercado ou compreender os perigos das substâncias que estão inseridas no ambiente. Pedrancini et al. (2008), no seu trabalho com estudantes do ensino médio, encontraram que os alunos, muitas vezes, expressam ideias equivocadas e sensacionalistas divulgadas pela mídia. Este fato também foi encontrado no trabalho de Cantisani et al. (2008), onde $37 \%$ dos alunos entrevistados disseram que aprendem temas relacionados à aplicação da genética através da televisão, enquanto apenas $24 \%$ disseram que estes temas são trabalhados na escola. As informações obtidas através da televisão não são suficientes para os alunos, pois estes não sabem selecionar e interpretar corretamente as notícias (Alves, 2005). 
Bons artigos de divulgação científica podem ser fontes complementares para professores do ensino fundamental, médio e universitário (Vieira, 2007).

Na questão 6 o tema é melhoramento genético. $\mathrm{O}$ texto abordava os agricultores que, desde milhares de anos, mesmo sem conhecimentos de genética e suas tecnologias, já utilizavam técnicas de melhoramento genético ao selecionarem as sementes provenientes das plantas mais produtivas (Santos, 2005).

Grande parte dos alunos - 79\% da escola A e 59\% da B - respondeu corretamente. Os alunos que erraram a questão justificaram afirmando que "melhoramento genético está relacionado com técnicas de laboratório".

A abordagem deste tema é um momento onde o professor pode utilizar a história como aliada para o aprendizado. Através da exposição de exemplos de plantas e animais selecionados ao longo do tempo, o aluno poderá compreender que o agricultor, ao guardar sementes das plantas mais produtivas, estará praticando a seleção genética.

A aprendizagem em genética requer o conhecimento adequado de diversos conceitos, entre eles está o termo genoma, que é considerado como um dos mais difíceis de ser compreendido.

O genoma é a informação genética completa contida em uma célula ou organismo. Este assunto ganhou destaque decorrente principalmente do Projeto Genoma Humano, finalizado em 2001, que identificou toda a sequência de nucleotídeos que formam o genoma de seres humanos. Este projeto envolveu a participação de diversos pesquisadores de vários países, trabalhando em conjunto para decifrar nosso genoma. O sequenciamento do genoma humano proporcionou uma nova visão do DNA para o século XXI (Franzolin e Bizzo, 2012). O estudo do genoma humano pode explicar as causas das doenças crônicas que afetam a saúde da população (Williams, 2012).

A questão 10 afirmava que o Projeto Genoma $\mathrm{Hu}-$ mano identificou todas as proteínas produzidas pelos seres humanos. A resposta com maior representação foi "estudei, mas esqueci", contra $10 \%$ de respostas corretas da escola A e $20 \%$ da escola B.

Aprender genética e suas correlações implica compreender conceitos subsunçores (Ausubel e col., 1980) e relacioná-los com temas mais específicos.

As questões relacionadas à bioética também estão cada vez mais presentes no cotidiano das pessoas. Discussões sobre as pesquisas com células-tronco embrionárias, identificação de produtos transgênicos, terapias gênicas e riscos ambientais, criam discussões e opiniões diversas entre estudantes. Por exemplo: é ético utilizar embriões, que não serão implantados, para pesquisas? As empresas têm que identificar nos rótulos os produtos transgênicos? Se, em um exame para a verificação de uma doença hereditária, for descoberto que o pai da criança não é o pai biológico, o geneticista tem direito de expor esta descoberta (Zatz, 2012)?
A questão 11 discutia se era ético utilizar sementes transgênicas em uma plantação antes de conhecermos os riscos para o ambiente. Entre os alunos, $44 \%$ da escola A e 38\% da escola B erraram a questão. Porém, nenhum deles justificou a resposta. Este fato pode estar relacionado à ausência de conhecimento com relação ao tema. Ao marcar a resposta e não justificar, o aluno se exime de expor uma opinião.

Estudantes, independente do nível de escolaridade, apresentam dificuldade em emitir opiniões esclarecidas em relação aos atuais avanços científicos e biotecnológicos (Sganzerla et al., 2004). Os conhecimentos debatidos no meio científico chegam até os alunos de uma forma resumida, insuficiente para gerar um conhecimento que os insiram no contexto do tema (Pedrancini et al., 2008).

Além disso, questões que envolvem bioética raramente são encontradas nos livros didáticos ou citadas pelos professores como um conteúdo importante a ser trabalhado na escola (Xavier et al., 2006).

Porém, com o crescimento da biotecnologia, cada vez mais, temas polêmicos surgirão e ganharão espaço e discussão nas mídias. Assim, cabe à escola e seus professores utilizarem o espaço da sala de aula para trabalhar estes temas e formar cidadãos com conhecimentos científicos corretos. Somente pela educação chega-se a um nível de esclarecimento que capacite à população entender, discutir eticamente e opinar sobre os novos rumos da ciência (Alves, 2005).

Nos Estados Unidos, temas como o uso de embriões para o estudo de células-tronco geraram um plebiscito, onde a população votou se era contra ou a favor das pesquisas (Zanato, 2006). No Brasil não ocorreu este tipo de ação, mas escolhemos políticos que irão votar estes projetos.

Então, independentemente de trabalharmos com genética e suas aplicações, é necessário que a população apresente conhecimento correto com relação a estes temas, para realizar escolhas de forma correta e confiável. Estudar genética é essencial para que os estudantes possam formar um conhecimento qualificado com relação a diferentes temas, tais como células-tronco e clonagem (Kovaleski e Araújo, 2013).

Ao analisarmos a Tabela 2, percebemos que todas as questões apresentam, em maior ou menor grau de porcentagem, a resposta "nunca estudei no colégio". Este resultado mostra que há uma deficiência na abordagem destes temas nas escolas ou o ensino não contribui para a formação de um conhecimento satisfatório. Muitas vezes, os professores apresentam suas próprias concepções em relação ao tema ou desconhecem o assunto. Então, para evitar discussões em sala de aula, acabam optando por não abordar temas polêmicos. Mas o professor, independente das suas crenças e opiniões, tem o dever de apresentar e trabalhar temas diversos, como transgenia, clonagem, terapias gênicas, células tronco, pois seus alunos poderão se deparar com questões referentes a estes assuntos e terão que opinar ou fazer 
escolhas relativas a elas.

É papel da escola contribuir para que os alunos compreendam aspectos relacionados com as aplicações tecnológicas e sociais dos conhecimentos na área da genética. $\mathrm{O}$ uso de temas relacionados à biotecnologia pode favorecer o gosto do aluno em aprender genética (Camargo, 2007). Estudos mostram que os próprios docentes sentem dificuldades para compreender temas relacionados aos conhecimentos produzidos na atualidade (Amorim, 1997) ou acreditam que determinadas características, como o homossexualismo, são hereditárias ou que os homens são mais inteligentes que as mulheres (Cástera e Clément, 2012).

Encontramos em Cachapuz et al. (2011, p. 20):

Num mundo repleto pelos produtos da indagação científica, a alfabetização científica converteu-se numa necessidade para todos: todos necessitamos utilizar a informação científica para realizar opções que se nos deparam a cada dia; todos necessitamos ser capazes de participar em discussões públicas sobre assuntos importantes que se relacionam com a ciência e com a tecnologia; e todos merecemos compartilhar a emoção e a realização pessoal que pode produzir a compreensão do mundo natural.

Desta forma, não há como a escola se omitir frente à necessidade da formação científica dos alunos.

\section{Conclusão}

A relação com genética ultrapassa as fronteiras da sala de aula e da necessidade de responder exercícios. Utilizamos os conhecimentos de genética em diferentes situações: ao ler no rótulo de um salgadinho que ele é fabricado com milho transgênico; ao escolher produtos de beleza que apresentam na embalagem a sigla DNA; quando opinamos sobre a legalização ou não do estudo das células- tronco; ao nos referirmos aos clones como "monstros" criados por cientistas ou, até mesmo, quando perguntamos por que uma criança é mais parecida com um dos seus pais.

Para que a compreensão destes temas seja adequada, importantes conceitos precisam estar aprendidos, como genes, alelos, cromossomos, meiose, mitose, variação genética, DNA, entre outros.

Porém, encontramos que a maior parte dos alunos participantes da pesquisa apresenta concepções errôneas relacionadas à genética, principalmente com relação às aplicações desta ampla área do conhecimento.

Independentemente da escola, particular ou públi$\mathrm{ca}$, as diferenças nas respostas não são significativas para que possamos concluir que, em uma das escolas, a aprendizagem ocorreu de forma mais significativa.

Percebemos um grande número de alunos respondendo que "estudaram, mas esqueceram", o que pode ser o resultado de um modelo de ensino descontextualizado que preza pela memorização de conceitos.

Também, em algumas questões os alunos disseram nunca ter estudado o conteúdo, principalmente naqueles temas relacionados à aplicação da genética. A carga horária pequena, a pressão relacionada aos vestibulares e a falta de conhecimento por parte de alguns professores podem ser fatores que levam a este resultado.

Refletir e buscar soluções para o ensino de biologia se torna essencial em uma sociedade tecnológica onde há manipulação do DNA, clonagem, produção de transgênicos e onde a mídia coloca a dispor da população erros conceituais relacionados ao assunto que está sendo tratado, o que leva à formação de concepções equivocadas pela maioria da população.

Este estudo teve seu foco nos estudantes de ensino médio, mas a revisão de literatura mostrou que professores se sentem despreparados para realizar estas mudanças em sala de aula, seja por falta de tempo, do conhecimento de metodologias adequadas ou o atrelamento aos concursos para a entrada nas universidades.

Assim, deixamos nossa mensagem de que a educação deve ser realizada de forma integral e buscando a autonomia do aluno, pois o homem é o único ser que transforma o seu ambiente. É nosso dever guiar o aluno para que estas mudanças sejam benéficas e sustentáveis à sociedade.

\section{Referências}

Alves, S. B. F; Caldeira, A. M. de A. Biologia e ética: um estudo sobre a compreensão e atitudes de alunos do ensino médio frente ao tema genoma/ DNA. Ensaio. v. 7, n. 1, 2005.

Amabis, J. M.; Martho, G. R. Biologia: biologia das populações. 3.ed. São Paulo: Moderna, 2009.

Amorim, A. C. R. O ensino de biologia e as relações entre ciência/ tecnologia e sociedade: o que dizem os professores e o currículo do ensino médio? Em: Anais do VI Encontro "Perspectivas do Ensino de Biologia". (p. 74- 77), 1997. São Paulo: Faculdade de Educação da USP.

Ausubel, D.P.; Novak, J. Hanesian H. Psicologia educacional. Tradução: Eva Nick. Rio de Janeiro: Editora Interamericana Ltda., 1980.

Ayuso, G. E.; Banet, E. Alternativas a la enseñanza de la genética en educación secundaria. Enseñanza de las Ciencias, v. 20, n. 1, p. 133-157, 2002.

Barbosa, M.V. Oficinas práticas de genética molecular para estudantes do ensino fundamental e médio no município de Garanhuns. In $54^{\circ}$ Congresso Brasileiro de Genética, p.2 Salvador, 2008. 
Disponível em http://web2.sbg.org.br/congress/ sbg2008/pdfs2008/23754.pdf Acesso em 31 de março de 2014.

Boneti, L.W. Educação, Exclusão e Cidadania. 3. ed. Rio Grande do Sul: Unijuí, 2006.

Brasil. Ministério da Educação. Secretaria de Educação Média e Tecnológica. Parâmetros Curriculares Nacionais (Ensino Médio). Brasília: MEC, 2000.

Cachapuz, A.; Gil-Perez, D.; Carvalho, A. M. de; Praia, J; Vilches, A. (organizadores). A necessária renovação do ensino das ciências. 2. ed. São Paulo: Cortez, 2011.

Camargo, S. S. A genética humana no ensino médio: algumas propostas. Genética na escola. v. 12. n. 1. p. 14-16, 2007.

Cantisani, L. F.; Mota, A. J. de; Mamede, M. G.; Cardoso, M. A. G. Quem é esse DNA? A incrível molécula da vida. IN IX Encontro Latino Americano de Iniciação Científica e V Encontro Latino Americano de Pós-Graduação. Universidade do Vale do Paraíba, 2008.

Carvalho, A. M. P. de Construção do conhecimento e ensino de ciências. Em Aberto. Ano 11. n. 55. p. 8-16, 1992.

Castelão, T.B. Amabis, J. M. Motivação e ensino de genética: um enfoque Atribucional sobre a escolha da área, prática docente e aprendizagem. In $54^{\circ}$ Congresso Brasileiro de Genética, p.5 Salvador, 2008.

Cástera, J.; Clément, P. Teacher's conceptions about the genetic determinismo of human behavior: a survey in 23 countries. Science \& Education. 2012.

Franzolin, F.; Bizzo, N. Conteúdos de genética básicos para a formação de cidadãos críticos no ensino médio segundo professores e docentes: em comparação com o defendido na literatura. IX ANPED SUL: Seminário de Pesquisa em Educação da Região Sul, 2012.

Franzolin, F. Conhecimentos básicos de Genética segundo professores e docentes e sua apresentação em livros didáticos e na academia: aproximações e distanciamentos. Tese de Doutorado. Pós Graduação em Educação. USP, 2012.

Gericke, N.M., El-Hani, C.N., dos Santos V.C. Conceptual variations or incoherence? Textbook discourse on genes in six countries. Science \& Education. v. 23, n. 2, p. 381-416, 2012.

Giacoia, L. R. D. Conhecimento básico de genética: concluintes do ensino médio e graduandos de ciências biológicas. Dissertação de Mestrado. Universidade Estadual Paulista. Faculdade de Ciências. Bauru / SP, 2006.

Godim, J. R.; Matte, U. Projeto Genoma Humano, Bioética e Genética: UFRGS, 2000. Disponível em http://www.ufrgs.br/bioetica/genoma.htm. Acesso em 10 de abril de 2014.

Hoffman, R. Por que divulgar ciência. Ciência Hoje. v.14. n. 182. p. 45, 1992.

Justina, L. A. D.; Barradas. C. M. As opiniões sobre o ensino de genética numa amostra de professores de biologia do nível médio. IN IV Encontro Nacional de Pesquisa em Educação em Ciências. Bauru, 2003.

Justina, L. A. D. Ensino de genética e história dos conceitos relativos à hereditariedade. Dissertação de Mestrado. Florianópolis: UFSC, 2001.

Kim, S. Y.; Irving, K. E. History of science as an instructional context: student learning in genetics and nature of science. Science \& Education. v. 19, n.2, p. 187-215, 2010.

Klautau, N.; Aurora, A.; Dulce, D.; Silviene, S.; Helena, H.; Correia, A. Relação entre herança genética, reprodução e meiose: um estudo das concepções de estudantes universitários do Brasil e Portugal. Enseñanza de las Ciencias, Número extra VIII Congreso Internacional sobre Investigación en Didáctica de las Ciencias, Barcelona, p. 2267-2270, 2009.

Kovaleski, A. B.; Araújo, M. C. P. de. A história da ciência e a bioética no ensino de genética. Genética na Escola. v.8, n.2, 2013.

Krasilchik, M.. Prática de Ensino de Biologia. 4 ed. São Paulo: Universidade de São Paulo, 2004.

Kreuzer, H, Massey, A. Engenharia genética e biotecnologia. 2 ed. São Paulo: Artmed, 2002.

Lane, S.; Codo, W. Psicologia social: o homem em movimento. São Paulo: Brasiliense, 1993.

Loreto, E.L.S.; Sepel, L.M.N. A escola na era do DNA e da Genética. Ciência e Ambiente. v. 6. p. 149-156, 2003. 
Ludke, A. e Menga, E.D.A. Pesquisa em Educação: abordagens qualitativas. São Paulo: EPU, 1986.

Meyer, L. M. N.; Bomfim, G. C.; El-Hani, C. N. How to understand the gene in the twenty-first century? Science \& Education, 2011.

Miranda, S. No fascínio do jogo, a alegria de aprender. Ciência Hoje, v.28, n. 168, p. 64-66, 2001.

Moreira, M.C.A. Silva, E.P. Concepções prévias. Uma revisão de alguns resultados sobre genética e evolução. Encontro Regional de Ensino de Biologia, Niterói, 2001.

Moreira, M. A. Unidades de enseñanza potencialmente significativas. Aprendizagem Significativa em revista. v. 1 (2). p. 43- 63, 2011.

Mortimer, E.F. Construtivismo, mudança conceitual e ensino de ciências: para onde vamos. Investigações em Ensino de Ciências, n.1, v.1, p. 20-39, 1996.

Neves, J. L. Pesquisa qualitativa- características, usos e possibilidades. Caderno de Pesquisas em Administração. São Paulo, v.1 no. 3 2․ Semestre 1996.

Pedrancini, V. D.; Corazza-Nunes, M. J.; Galuch, T. B.; Moreira, A. L. O. R.; Nunes, W. M. de C. Saber científico e conhecimento espontâneo: opiniões de alunos do ensino médio sobre transgênicos. Ciência e Educação. v. 14, n. 1, p. 135-146, 2008.

Pedrancini, V. D.; Corazza-Nunes, M. J.; Galuch, T. B.; Moreira, A. L. O. R.; Ribeiro, A. C. Ensino e aprendizagem de biologia no ensino médio e a apropriação do saber científico e biotecnológico. Revista Electrónica de Enseñanza de las Ciencias. v. 6, n. 2, p. 299-309, 2007.

Primon, C.S.F. Análise do conhecimento de conteúdos fundamentais de Genética e Biologia Celular apresentado por graduandos em Ciências Biológicas. São Paulo. Instituto de Biociências, Universidade de São Paulo, 2005. Dissertação de Mestrado em Biologia/Genética, 2005.

Redfield, R. J. Why do we have to learn this stuff? A new genetics for 21st century students. Plos Biology. v. 10. n. 7, 2012.

Santos, A dos. Experimentação lúdica no ensino de genética: mitose. Monografia (graduação) Licenciatura Plena em Biologia, ULBRA, Itumbiara, 2008.
Santos, S. Para geneticistas e educadores: o conhecimento cotidiano sobre a herança biológica. São Paulo: Annablume, 2005.

Scheid, N. M. J.; Ferrari, N. A história da ciência como aliada no ensino de genética. Genética na escola. v. 1, n. 1. p. 17-18, 2006.

Sganzerla, L. C. M.; Corazza-Nunes, M. J.; Nunes, W. M.; Tomanik, E. A. Preparados ou não para o futuro? Atitudes dos alunos de graduação em relação ao projeto genoma humano. Acta Scientiarum. n. 26, v.2, p. 239-250, 2004.

Silveira, R. V. M. Código genético: uma análise das concepções dos alunos do ensino médio. Genética na escola. v.9, n.1, p. 12-19, 2014.

Temp, D. S.; Bartholomei- Santos, M. L. Desenvolvimento e uso de um modelo didático para facilitar a correlação genótipo-fenótipo. Revista Electrónica de Investigação em Educação em Ciências. v.8, n.2., p. 13-20, 2013.

Vieira, C. L. Pequeno manual de divulgação científica. 3 ed. Rio de janeiro: Instituto Ciência Hoje, 2007.

Williams, M., Montgomery, B. L., Manokore, V. From phenotype to genotype: exploring middle school student's understanding of genetic inheritance in a web-based environment. v. 74, n. 1, p. 35-40, 2012.

Xavier, M.C.F.; Freire, A. S.; Moraes, M. O. A nova (moderna) biologia e a genética nos livros didáticos de biologia no ensino médio. Ciência e Educação. v. 12. v. 3, p. 275-289, 2006.

Zanato, L. Células-tronco embrionárias e a lei 11.105/05: convergências entre biologia e direito. Monografia (graduação) bacharelado em Direito. UFPR. Curitiba, 2006.

Zatz, M. Genética: a escolha que nossos avós não faziam. São Paulo: Globo, 2012. 


\section{ANEXO 1: Pesquisa realizada com os alunos}

\section{Ensino e aprendizagem de genética e suas aplicações: identificando o conhecimento presente entre concluintes do ensino médio}

Pesquisador (a): Daiana Sonego Temp

e-mail: daianatemp@yahoo.com.br

Orientador(a): Marlise Ladvocat Bartholomei-Santos e-mail: marliselbs@gmail.com

Caro aluno, você está sendo convidado para participar como voluntário, em uma pesquisa de doutorado do PPG Educação em Ciências: Química da Vida e Saúde da Universidade Federal de Santa Maria. As respostas são confidenciais e utilizadas no todo sem haver identificação do estudante.

Obrigada pela sua participação.

\section{TERMO DE CONSENTIMENTO LIVRE E ESCLARECIDO}

$\mathrm{Eu}$, RG

concordei em responder a pesquisa abaixo. Fui esclarecido sobre a mesma e de que não terei minha identidade revelada bem como não terei nenhuma remuneração.

Dados gerais:

Sexo: ( ) F ( ) M

Idade:

Quero fazer vestibular para:

Após analisar as afirmativas, assinale a letra que corresponde a melhor resposta para as questões a seguir: (V) verdadeira, (F) falsa, (E) estudei, mas esqueci e (N) não vi isso no colégio. Ao final de cada questão que você responder como FALSA, dê uma breve explicação para sua resposta.

1. Nos exames para teste de paternidade, o DNA, quando extraído do sangue, pode ser obtido a partir das hemácias, dos leucócitos ou das plaquetas, pois todas as células apresentam o DNA.

(V) verdadeira estudei, mas esqueci

(F) falsa

( E )

(N) não vi isto no colégio.

2. Em um acidente, embora os corpos das vítimas fatais ficassem queimados e irreconhecíveis, foi possível obter, a partir de fragmentos de tecidos, amostras de DNA nuclear e mitocondrial de todos os mortos. Faleceram no acidente dois filhos de uma senhora, cada um de um casamento diferente. Uma das formas possíveis de identificar os despojos dos filhos dessa senhora consiste em verificar se existe homologia (similaridade) do DNA mitocondrial da senhora com o DNA mitocondrial das vítimas, pois o DNA mitocondrial é herdado sempre da mãe.

(V) verdadeira estudei, mas esqueci
(F) falsa ( E )

(N) não vi isto no colégio.

\section{Analise a situação fictícia abaixo:}

Ambas reclamam na Justiça o reconhecimento de paternidade, determinando o juiz a realização de testes de DNA. Em cada caso, os testes usaram para comparação amostras da criança e de sua mãe, e do(s) suposto(s) pai(s). Após receber os resultados, a Justiça pronunciou-se sobre a paternidade de uma das crianças: Renato porque a mãe teve relações com gêmeos monozigóticos.

\section{(V) verdadeira}

estudei, mas esqueci

4. A égua, o jumento e a zebra pertencem a espécies biológicas distintas que podem cruzar entre si e gerar híbridos estéreis. Destes, o mais conhecido é a mula, que resulta do cruzamento entre o jumento e a égua. Suponha que o seguinte experimento de clonagem foi realizado com sucesso: o núcleo de uma célula somática de um jumento foi transplantado para um óvulo anucleado da égua e o embrião foi implantado no útero de uma zebra, onde ocorreu a gestação. $\mathrm{O}$ animal (clone) produzido em tal experimento terá características genéticas da égua, pois ela foi a doadora do gameta (óvulo).

\section{(V) verdadeira}

estudei, mas esqueci

(F) falsa

(N) não vi isto no colégio.

5. Há diversos tipos de milhos disponíveis no campo. Alguns são mais resistentes à ação de determinadas pragas, enquanto outros apresentam maior teor de amido. Atualmente, com o avanço científico-tecnológico, tem sido possível unir essas duas características em um único organismo, incorporando em seu DNA um ou mais genes de outros organismos, responsáveis pelas características desejadas. Um organismo que apresenta genes de outros organismos recebe o nome de transgênico.

(V) verdadeira estudei, mas esqueci
(F) falsa ( E ) (N) não vi isto no colégio.

6. Durante milênios, os agricultores aperfeiçoaram a natureza criando diferentes espécies e variedades vegetais para obter plantas com determinada característica genética. Mesmo sem possuir conhecimentos científicos, eles já aplicavam técnicas de melhoramento genético.

(V) verdadeira

estudei, mas esqueci

. Novas técnicas possibilitaram a produção de grandes quantidades de insulina por bactérias que receberam o gene humano para esse hormônio. O fato citado é um exemplo de utilização de técnicas de engenharia genética.
(V) verdadeira

estudei, mas esqueci
(F) falsa ( E ) 
8. Alba é uma doce coelhinha branca, nascida na França em abril, e vive num centro de pesquisas. A coelhinha recebeu um trecho de DNA de medusa que a faz brilhar na presença da luz. Para a produção de Alba foi necessário inserir o DNA da medusa em todas as células de Alba.
(V) verdadeira estudei, mas esqueci
(F) falsa ( E )

(N) não vi isto no colégio.
9. Teste de DNA confirma paternidade de bebê perdido no tsunami. Um casal do Sri Lanka que alegava ser os pais de um bebê encontrado após o tsunami que atingiu a Âsia, em dezembro, obteve a confirmação do fato através de um exame de DNA. O menino, que ficou conhecido como "Bebê $81^{\prime \prime}$ por ser o $81^{\circ}$ sobrevivente a dar entrada no hospital de Kalmunai, era reivindicado por nove casais diferentes. Folha online, 14/02/2005 (adaptado). Algumas regiões do DNA apresentam sequências curtas de nucleotídeos que se repetem no genoma (por exemplo, GATCGATCGATCGATC), e o número de repetições dessas regiões varia entre as pessoas. Existem procedimentos que permitem visualizar essa variabilidade, revelando padrões de fragmentos de DNA que são uma impressão digital molecular. Não existem duas pessoas com o mesmo padrão de fragmentos com exceção dos gêmeos monozigóticos. Metade dos fragmentos de DNA de uma pessoa é herdada de sua mãe e a outra metade de seu pai. Com base nos padrões de fragmentos de DNA representados abaixo, podem ser considerados como pais biológicos do Bebê 81 o casal D.

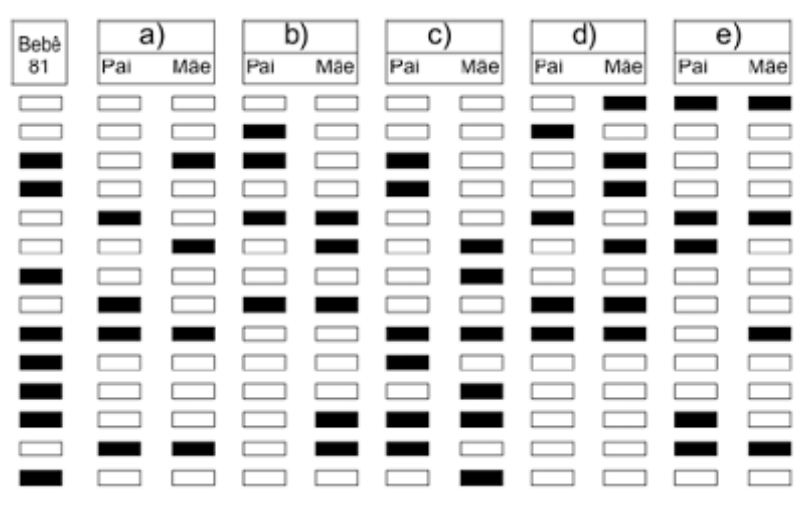

(V) verdadeira

(F) falsa

( E ) estudei, mas esqueci

(N) não vi isto no colégio.

10. O anúncio do sequenciamento do genoma humano, em 21 de junho de 2000, significa que os cientistas determinaram todos os tipos de proteínas codificadas pelos genes humanos.
(V) verdadeira estudei, mas esqueci
(F) falsa ( E )

(N) não vi isto no colégio.
11. A aplicação das técnicas que compõem a Biotecnologia Molecular tem implicações econômicas, éticas, sociais e legais. A Bioética é um campo interdisciplinar que procura antecipar os problemas éticos relacionados com a pesquisa biológica e seu impacto na sociedade. Assim, não há riscos, ou seja, não é antiética a utilização de plantas geneticamente modificadas para resistência a herbicidas, pois não há risco delas passarem a característica adquirida para outras plantas semelhantes no ambiente, criando seres resistentes aos herbicidas.
$(\mathrm{V})$ verdadeira
(F) falsa
( E )

estudei, mas esqueci

(N) não vi isto no colégio.

12. João e Maria estão pensando em ter um filho. João tem um irmão moreno claro e uma irmã morena escura. Seu pai é moreno claro e sua mãe é negra. Maria e seus pais são brancos. A característica cor da pele se refere ao genótipo do individuo, ou seja, a interação do ambiente com o fenótipo.
(V) verdadeira

(F) falsa

(N) não vi isto no colégio. estudei, mas esqueci

Fonte das questões utilizadas no teste com os alunos

\begin{tabular}{|c|c|}
\hline Questão & Fonte \\
\hline 1 & $\begin{array}{l}\text { http://nhccosmeticos.com.br/paulobhz/ } \\
\text { Biotecnologia.pdf }\end{array}$ \\
\hline 2 & $\begin{array}{l}\text { file:///C:/Documents } \% 20 \text { and } \% 20 \text { Settings / } \\
\text { matheus/Meus } \% 20 \text { documentos/Downloads/ } \\
\text { exerciciosengenharia-geneticaparte } 01 \% 20(1) . p d f\end{array}$ \\
\hline 3 & $\begin{array}{l}\text { http://nhccosmeticos.com.br/paulobhz/ } \\
\text { Biotecnologia.pdf }\end{array}$ \\
\hline 4 & $\begin{array}{l}\text { file:///C:/Documents } \% 20 \text { and } \% 20 \text { Settings / } \\
\text { matheus/Meus } \% 20 \text { documentos/Downloads / } \\
\text { exerciciosengenharia-geneticaparte01.pdf }\end{array}$ \\
\hline 5 & $\begin{array}{l}\text { h t t p : / / d j a l m a s a n to s.w ord p res s. } \\
\text { com/2011/11/10/testes-de-biotecnologia-55/ }\end{array}$ \\
\hline 6 & $\begin{array}{l}\text { h t t p : / / d j a l m a s a n to s.w ord p ress. } \\
\text { com/2011/11/10/testes-de-biotecnologia-55/ }\end{array}$ \\
\hline 7 & $\begin{array}{l}\text { file:///C:/Documents } \% 20 \text { and } \% 20 \text { Settings / } \\
\text { matheus/Meus } \% 20 \text { documentos/Downloads/ } \\
\text { exerciciosengenharia-geneticaparte01.pdf }\end{array}$ \\
\hline 8 & $\begin{array}{l}\text { http://nhccosmeticos.com.br/paulobhz/ } \\
\text { Biotecnologia.pdf }\end{array}$ \\
\hline 9 & $\begin{array}{l}\text { file:///C:/Documents } \% 20 \text { and } \% 20 \text { Settings/ } \\
\text { matheus/Meus } \% 20 \text { documentos/Downloads/ } \\
\text { exerciciosengenharia-geneticaparte01.pdf }\end{array}$ \\
\hline 10 & $\begin{array}{l}\text { file:///C:/Documents } \% 20 \text { and } \% 20 \text { Settings / } \\
\text { matheus/Meus } \% 20 \text { documentos/Downloads/ } \\
\text { exerciciosengenharia-geneticaparte01.pdf }\end{array}$ \\
\hline 11 & $\begin{array}{l}\text { http://nhccosmeticos.com.br/paulobhz/ } \\
\underline{\text { Biotecnologia.pdf }}\end{array}$ \\
\hline 12 & http://www.passeidireto.com/arquivo/ \\
\hline
\end{tabular}

